\title{
EVIDENCE ON LEARNING AND NETWORK EXTERNALITIES IN THE DIFFUSION OF HOME COMPUTERS*
}

\author{
AUSTAN GOOLSBEE and PETER J. KLENOW \\ University of Chicago Federal Reserve Bank \\ of Minneapolis
}

\begin{abstract}
In this paper we examine the importance of local spillovers-such as network externalities and learning from others-in the diffusion of home computers. We use data on 110,000 U.S. households in 1997. Controlling for many individual characteristics, we find that people are more likely to buy their first home computer in areas where a high fraction of households already own computers or when a large share of their friends and family own computers. Further results suggest that these patterns are unlikely to be explained by common unobserved traits or by area features. When looked at in more detail, the spillovers appear to come from experienced and intensive computer users. They are not associated with the use of any particular type of software but do seem to be highly tied to the use of e-mail and the Internet, consistent with computers being part of an information or communication network.
\end{abstract}

\section{INTRODUCTION}

I $\mathrm{N}_{\mathrm{N}}$ this paper, we empirically examine the importance of local spillovers-such as network externalities and learning from others-in the diffusion of home computers. Technology diffusion plays a central role in many theories of development and economic growth. ${ }^{1}$ Some recent studies have singled out computer diffusion as an engine of growth and as a potential

* We thank Severin Borenstein, Anne Case, Judy Chevalier, Leora Friedberg, Shane Greenstein, Tom Holmes, Boyan Jovanovic, Anil Kashyap, Lawrence Katz, Steven Levitt, Peter Pashigian, Alwyn Young, the editor, and a referee for helpful comments and the American Bar Foundation, the National Science Foundation, and the University of Chicago Graduate School of Business for financial support.

${ }^{1}$ See Gene M. Grossman \& Elhanan Helpman, Innovation and Growth in the Global Economy (1991); and Stephen L. Parente \& Edward C. Prescott, Barriers to Technology Adoption and Development, 102 J. Pol. Econ. 298 (1994).

[Journal of Law and Economics, vol. XLV (October 2002)]

(C) 2002 by The University of Chicago. All rights reserved. 0022-2186/2002/4502-0002\$01.50 
source of fundamental labor market changes. ${ }^{2}$ In addition, network externalities are of recurring interest in industrial organization and public economics. ${ }^{3}$

We employ a database of the computer ownership and purchase decisions of more than 110,000 U.S. households. ${ }^{4}$ Our notion is that people without computers may learn about the technology from their computer-owning friends and neighbors or benefit from the size of the local computer "network" because they can share software or communicate with one another. If so, there may be positive spillovers from existing computer owners to new owners.

Because local households may have traits in common and face similar economic environments, establishing the existence of local spillovers is difficult. People who live in places where a high share of people already own computers may have a greater affinity for technology, even if they do not already own a computer, and therefore may be more likely to become owners. Also, high adoption rates may reflect low local computer prices or the prevalence of local computer-making and computer-using firms. This problem pervades the empirical work on local effects. We employ several strategies to test whether common traits or common economic environments, as opposed to network or learning benefits, can explain our findings.

The existence of learning or network externalities in computer adoption could have important policy implications. Externalities could mean that the rate of adoption is too slow, possibly justifying public subsidies to computer or Internet adoption or expanded teaching of computer skills in schools. In this spirit, the U.S. government has a number of programs designed to close the "digital divide" between users and nonusers of the Internet. ${ }^{5}$

${ }^{2}$ Discussions of computers as engines of growth include Timothy F. Bresnahan \& Manuel Trajtenberg, General Purpose Technologies: "Engines of Growth"? 65 J. Econometrics 83 (1995); Jeremy Greenwood \& Mehmet Yorukoglu, 1974, 46 Carnegie-Rochester Conf. Ser. Pub. Pol'y 49 (1997); and Martin Neil Baily \& Robert Z. Lawrence, Do We Have a New Economy? 91 Am. Econ. Rev. 308 (2001). For the impact of computers on the labor market, see David H. Autor, Lawrence F. Katz, \& Alan B. Krueger, Computing Inequality: Have Computers Changed the Labor Market? 113 Q. J. Econ. 1169 (1998).

${ }^{3}$ Joseph Farrell \& Garth Saloner, Standardization, Compatibility and Innovation, 16 Rand J. Econ. 70 (1985), and Michael Katz \& Carl Shapiro, Technology Adoption in the Presence of Network Externalities, 94 J. Pol. Econ. 822 (1986), provide early analyses of network externalities. Nicholas Economides, Economics of Networks, 14 Int'1 J. Indus. Org. 673 (1996), surveys the more recent literature. Philip H. Dybvig \& Chester S. Spatt, Adoption Externalities as Public Goods, 20 J. Pub. Econ. 231 (1983), gives an overview of the implications for public economics.

${ }^{4}$ For investigation into the adoption of computers by firms, see Timothy F. Bresnahan \& Shane Greenstein, Technical Progress and Co-invention in Computing and in the Uses of Computers, 1996 Brookings Papers on Econ. Activity: Microecon. 1; and Timothy F. Bresnahan, Scott Stern, \& Manuel Trajtenberg, Market Segmentation and the Sources of Rents from Innovation: Personal Computers in the Late 1980s, 28 Rand J. Econ. 17 (Supp. 1997).

${ }^{5}$ See http://www.digitaldivide.gov for an overview. See Jerry Hausman, Taxation by Telecommunications Regulation, 12 Tax Pol'y \& Econ. 29 (James M. Poterba ed. 1998), for a 
Externalities would mean that such programs have a overall effect on adoption that is greater than their direct effects, since the new adopters induce others to adopt as well. From an efficiency standpoint, subsidies should target those most responsive to subsidies and those groups that confer the greatest externalities. If externalities come from any amount of use of a home personal computer, then subsidies for first-time household purchases (if feasible) would make more sense than subsidizing all purchases. If externalities instead come from experienced, intensive users, then more narrowly targeted subsidies might be warranted. Subsidies might also target adoption within isolated subgroups on the wrong side of the digital divide because doing so could affect a larger set of nonusers.

An important caveat to drawing any policy implications from evidence on local learning or network spillovers is that such evidence is not the same as evidence of externalities. The recipients of spillover benefits may compensate the providers (for example, "I'll take you to lunch if you will show me how to use this computer"). In keeping with the existing literature, we will refer to learning and network externalities. Since the distinction between externalities and spillovers is fundamental but unobservable, in this paper we will focus primarily on documenting the spillovers.

In the empirical results that follow, we find evidence consistent with local spillovers in home computer adoption. Using instruments, additional control variables, and a variety of tests and sample periods, we find little evidence that the effects are the result of correlated individual traits within cities or city features such as industry composition, availability of computer retailers, or level of computer prices.

The data do suggest that the spillovers are concentrated in local areas and among family and friends. The spillovers appear to be greatest from experienced and intensive computer users. The spillovers do not appear to be tied to the use of any particular type of software (spreadsheets, word processors, graphics, games, or family budgeting) but are highly tied to the use of e-mail and the Internet. This is consistent with the idea that the computer serves as a part of a local information or communication network.

The rest of the paper proceeds as follows. In Section II, we describe previous work in related areas. In Section III, we describe the data set and our empirical specification. In Section IV, we present ordinary least squares (OLS) estimates of local spillovers. In Section V, we deploy instruments to deal with possible simultaneity problems. In Section VI, we investigate the

discussion of the $\$ 2.25$ billion annual U.S. federal subsidy for public school and library Internet access financed by a special tax on phone service. There have been more ambitious (albeit geographically concentrated) subsidies as well, including the Blackburg Electronic Village program in Virginia and the Information Age Town program in Ennis, Ireland. In these cities, attempts were made to put a computer in every household and school and to connect everyone to the Internet. For descriptions of these programs, see John Yaukey, Blacksburg, Va.: A Town That's Really Wired, Ithaca J., April 8, 1997; and Sean MacCarthaigh, Technology Town, Irish Times, November 14, 1997. 
nature of the spillovers and try to identify the source of the network benefits. In Section VII, we conclude.

\section{Related Literature}

Network externalities arise when the value of participating in a network increases as more people participate in the network. This could apply to literal networks such as the telephone or e-mail systems, as well as to complementary goods such as videocassette recorders (VCRs) and videocassettes. To the extent that there are one-time costs of joining a network or switching to a different network (for example, buying a cellular phone compatible with only one type of network), the literature finds that network externalities can lead to inefficient outcomes. Such outcomes run the gamut from suboptimally fast adoption to suboptimally slow adoption, from locking in an inefficient technology to abandoning a superior technology for an inferior one. ${ }^{6}$ The classic example of how network externalities can ensconce an inefficient technology is the QWERTY typewriter keyboard. The large number of users of the QWERTY layout allegedly makes manufacturers averse to producing a better layout, while the prevalence of QWERTY keyboards allegedly keeps users from wanting to learn a faster layout. ${ }^{7}$

Network externalities introduce dynamic considerations for both users and producers. For users, the adoption decision must take into account the size of the network in the future to avoid being stranded in an unpopular network. Firms have an incentive to invest in building proprietary networks from which they can earn rents. Discussion of these types of issues for the Internet browser market arose in the Microsoft antitrust trial ${ }^{8}$ and appear to be at the heart of the battle between Microsoft and America Online over instant-messaging networks. Systematic empirical work on network externalities has been relatively rare, however. There has been work on a few industries, including numerically controlled machines, spreadsheets, automated teller machines, prescription antiulcer drugs, and electronic bank payments. ${ }^{9}$

\footnotetext{
${ }^{6}$ See note 3 supra.

${ }^{7}$ This example is not without controversy. Paul A. David, Clio and the Economics of QWERTY, 75 Am. Econ. Rev. 332 (1985), forwards the QWERTY hypothesis, but S. J. Liebowitz \& Stephen E. Margolis, Network Externality: An Uncommon Tragedy, 8 J. Econ. Persp. 133 (Spring 1994), challenges its validity.

${ }^{8}$ Richard J. Gilbert \& Michael L. Katz, An Economist's Guide to U.S. v. Microsoft, 15 J. Econ. Persp. 25 (Spring 2001).

${ }^{9}$ Massoud Karshenas \& Paul L. Stoneman, Rank, Stock, Order, and Epidemic Effects in the Diffusion of New Process Technologies: An Empirical Model, 24 Rand J. Econ. 503 (1993); Neil Gandal, Hedonic Price Indexes for Spreadsheets and an Empirical Test for Network Externalities, 25 Rand J. Econ. 160 (1994); Garth Saloner \& Andrea Shepard, Adoption of Technologies with Network Effects: An Empirical Examination of the Adoption of Automated Teller Machines, 26 Rand J. Econ. 479 (1995); Ernst R. Berndt, Robert S. Pindyck, \& Pierre Azoulay, Consumption Externalities and Diffusion in Pharmaceutical Markets: Antiulcer Drugs (Working Paper No. 7772, Nat'l Bur. Econ. Res. 2000); and Gautam Gowrisankaran \& Joanna
} 
Learning from others can also influence the spread of technology. In his classic study of the diffusion of hybrid corn in the United States, Zvi Griliches found evidence consistent with late adopters learning from early adopters. ${ }^{10}$ Controlling for land size and land quality (which affect the incentive to adopt hybrid corn), he found that hybrid corn was adopted earlier where corn farms were closer together. He interpreted this as suggesting that proximity facilitated communication between users and potential adopters, as well as sales visits by hybrid seed sellers. V. V. Chari and Hugo Hopenhayn argue that younger workers learn from older workers who are experienced with older technologies, thereby slowing the diffusion of new technologies. ${ }^{11}$ In their model, workers and firms find it optimal to continue to invest in human and physical capital specific to the old technology long after the arrival of a superior technology (for example, steam power rather than electric power).

As the examples above illustrate, a key prediction of models with network externalities and learning spillovers is that the adoption rate among nonadopters increases as the level of cumulative adoption increases. Usefully for empirical work, this prediction is not shared by other leading theories of diffusion. For example, suppose diffusion occurs because the price of acquiring the new technology decreases over time. As the price decreases, the technology is adopted by users who value the technology less and less. In this alternative view, the typical S-shaped diffusion curve may be mapping out the fixed distribution of reservation prices for adopting the technology, with the steep part of the S-curve merely reflecting a convex range of the cumulative distribution. In contrast, the spillovers explanation suggests a positive relationship between the adoption rate and cumulative adoption at all levels of cumulative adoption. We exploit this distinction in our tests below.

\section{Data AND Empirical Specification}

\section{A. Data}

The data we use come from a proprietary December 1997 mail survey by Forrester Research called Technographics $98 .{ }^{12}$ Forrester is a marketing

Stavins, Network Externalities and Technology Adoption: Lessons from Electronic Payments (unpublished manuscript, Univ. Minnesota 2001).

${ }^{10}$ Zvi Griliches, Hybrid Corn: An Exploration in the Economics of Technological Change, 25 Econometrica 501 (1957). Recent studies of learning from others have investigated patenting (Adam Jaffe, Manuel Trajtenberg, \& Rebecca Henderson, Geographic Localization of Knowledge Spillovers as Evidenced by Patent Citations, 108 Q. J. Econ. 577 (1991)), memory chip production (Douglas A. Irwin \& Peter J. Klenow, Learning-by-Doing Spillovers in the Semiconductor Industry, 102 J. Pol. Econ. 1200 (1994)), and hybrid seed adoption in rural India (Andrew Foster \& Mark Rosenzweig, Learning by Doing and Learning from Others: Human Capital and Technological Change in Agriculture, 103 J. Pol. Econ. 1176 (1995)).

${ }^{11}$ V. V. Chari \& Hugo Hopenhayn, Vintage Human Capital, Growth, and the Diffusion of New Technology, 99 J. Pol. Econ. 1142 (1991).

${ }^{12}$ More details on the Technographics program can be found in Josh Bernhoff, Shelley Morrisette, \& Kenneth Clemmer, Technographics Service Explained, Forrester Rep., January 
research company that specializes in the information economy. The fieldwork for the survey was conducted by the NPD Group, which received filled-out questionnaires from more than 110,000 American households on their ownership patterns for computers and other electronic goods. The sampling methodology is proprietary but is meant to ensure a nationally representative sample. We found only modest differences when we cross-checked median income, age, and marital status for several states in the sample against data reported by the U.S. Bureau of the Census. ${ }^{13}$ The Forrester data are widely respected in the industry, and private-sector companies pay significant amounts of money to access it.

For each respondent the data set contains demographic information, including gender, race, income, education, age, marital status, presence of children under 18, use of a computer at work, operation of a business from home, and state and broadly defined metropolitan area of residence. ${ }^{14}$ The data set also contains information on how much television they watch, their ownership of various electronic goods, and even some attitude variables such as ratings from 1 to 10 of how much they "like technology." All information was gathered in December 1997.

For respondents with a computer in 1997, the survey also contains information on how many computers they have, how many they have ever had, when they bought their first computer, when they bought their (up to) three most recent computers, how often they use their computer, and whether they have Internet access. For those without computers, the survey includes (selfreported) information on how likely they are to buy a computer in the next year and what share of their friends and family use computers.

Using this information, we are able to calculate what fraction of people in a city had a computer in 1996 (assuming no one moved) and what share of 1996 nonowners bought their first computer in 1997. We cannot get a true panel, however, because household information such as family composition is applicable only at the time of the survey.

Table 1 provides average demographic characteristics for households that owned a computer at the start of 1997, those that did not, those that bought their first home computer during 1997, and those that did not own a computer through 1997. ${ }^{15}$ Compared to nonowners, owners at the beginning of 1997 were better educated, richer, and so on. Likewise, among those not owning at

1998, at 1; and Austan Goolsbee, In a World without Borders: The Impact of Taxes on Internet Commerce, 115 Q. J. Econ. 561 (2000).

${ }^{13}$ U.S. Bureau of the Census, Current Population Reports. P60-200, Money Income in the United States: 1997 (1998).

${ }^{14}$ The respondents are divided into 208 metropolitan areas that are defined by the television market they reside in. These areas are generally larger than comparable standard metropolitan statistical areas. The San Francisco area, for example, includes all of the Bay Area.

${ }^{15}$ The sample in the second group consists of those in the last two groups. No households reported a change from owning at the beginning of 1997 to not owning at the end of 1997. 
TABLE 1

DEMOGRAPHICS OF 1997 NONOWNERS VERSUS OWNERS

\begin{tabular}{lcccc}
\hline \hline Variable & $\begin{array}{c}\text { Computer } \\
\text { Owners at the } \\
\text { Start of } 1997\end{array}$ & $\begin{array}{c}\text { Those Not } \\
\text { Owning at the } \\
\text { Start of 1997 }\end{array}$ & $\begin{array}{c}\text { Those Adopting } \\
\text { during 1997 }\end{array}$ & $\begin{array}{c}\text { Those Not } \\
\text { Owning } \\
\text { through 1997 }\end{array}$ \\
\hline Income & 53.7 & 31.4 & 44.2 & 30.3 \\
Age & $(30.5)$ & $(23.8)$ & $(27.9)$ & $(23.1)$ \\
Education & 44.5 & 49.0 & 43.0 & 49.5 \\
& $(13.2)$ & $(15.3)$ & $(13.5)$ & $(15.4)$ \\
Female & 14.5 & 12.8 & 13.6 & 12.8 \\
& $(2.4)$ & $(2.2)$ & $(2.3)$ & $(2.2)$ \\
Single & .466 & .589 & .522 & .594 \\
& $(.499)$ & $(.492)$ & $(.500)$ & $(.491)$ \\
Children aged 6-17 & .350 & .518 & .391 & .529 \\
& $(.477)$ & $(.500)$ & $(.488)$ & $(.499)$ \\
Asian & .358 & .219 & .352 & .208 \\
& $(.479)$ & $(.413)$ & $(.478)$ & $(.406)$ \\
Non-Asian Minority & .016 & .007 & .012 & .006 \\
& $(.126)$ & $(.082)$ & $(.111)$ & $(.079)$ \\
Use a Computer at Work & .098 & .134 & .122 & .135 \\
& $(.297)$ & $(.340)$ & $(.327)$ & $(.342)$ \\
Run a Business from Home & .684 & .314 & .592 & .290 \\
& $(.465)$ & $(.464)$ & $(.492)$ & $(.454)$ \\
$N$ & .181 & .090 & .164 & .083 \\
& $(.385)$ & $(.286)$ & $(.370)$ & $(.276)$ \\
& 40,472 & 61,399 & 4,967 & 56,432 \\
\hline
\end{tabular}

NotE. - Standard deviations are in parentheses. Education and age are in years, income is in thousands of dollars, and the other variables are in fractions of one.

the start of 1997, those adopting during 1997 were better educated, richer, and so on. At the start of 1997, 39.7 percent of households reported owning a computer; at the end of 1997, that number had increased to 44.6 percent. By comparison, the Electronic Industries Association estimated 40 percent ownership during 1997, and the Current Population Survey estimated 37 percent.

Figure 1 presents a map of end-of-1997 computer ownership rates by state. For the sample of 208 cities, Figure 2 plots the 1997 adoption rate (the percentage of households not owning at the beginning of 1997 that bought during 1997) against the fraction of households owning at the beginning of 1997. As shown, cities with high cumulative adoption rates through 1996 continue to have high adoption rates in 1997. The coefficient is 127 (standard error $=.025, t$-statistic $=5.0$ ). This may simply result from positively correlated demographics across households within a city, so we now proceed to examine the data on individual households.

\section{B. Empirical Specification}

We concentrate on the dichotomous choice facing people who do not yet have a home computer at the start of the year: whether or not to buy a computer. For household $i$ in year $t$, call this decision $y_{i t}$, where $y_{i t}=0$ if 


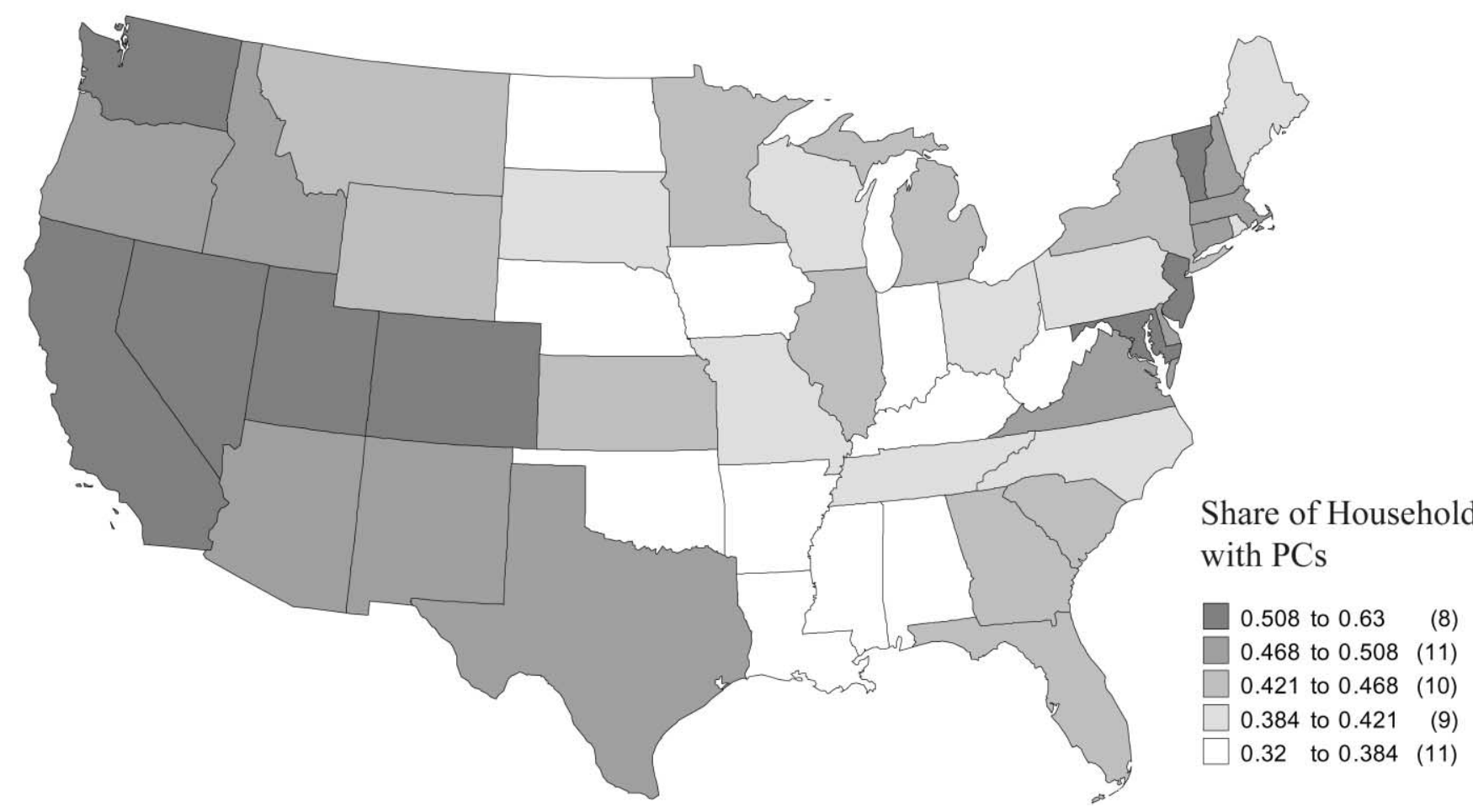

FIGURE 1.-Computer adoption across cities 


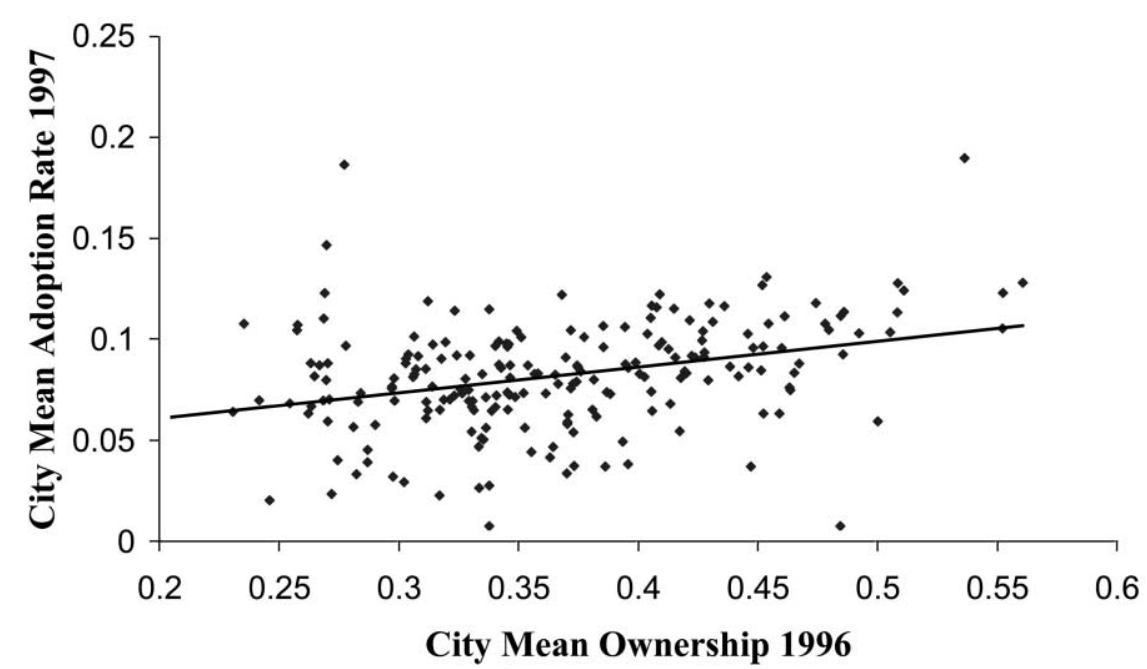

FIGURE 2.-City mean adoption rate

the household does not adopt and $y_{i t}=1$ if the household adopts. If $p_{i t}^{*}$ is household $i$ 's reservation price in year $t$ and $p_{i t}$ is the market price facing household $i$ in year $t$, then

$$
y_{i t}=1 \text { if } p_{i t}^{*} \geq p_{i t} \text { and } y_{i t}=0 \text { if } p_{i t}^{*}<p_{i t} .
$$

Consider a household that buys a computer in year $t$. Since this is the first purchase, this is the first year in which the market price of a computer has been below the household's reservation price. This may have come about because the market price decreased, the household's reservation price increased, or some combination. We specify that ${ }^{16}$

$$
\text { probability }\left(y_{i t}=1\right)=\lambda \operatorname{CITY} \%_{t-1}+\beta x_{i}^{\mathrm{o}}+x_{i t}^{\mathrm{u}}+c_{i t}^{\mathrm{u}}+u_{i t},
$$

where CITY\% ${ }_{t-1}$ is the fraction of households in the city that have a computer in the previous year. If there are local learning and network externalities, then nonowners who live in areas where owners are prevalent will be more likely to buy one (controlling for all other factors), leading to $\lambda>0$. This is analogous to epidemiology models in which an infectious disease spreads more quickly the larger the fraction of the population infected. In the marketing literature, this is known as the Bass model. ${ }^{17}$ We apply this model to

\footnotetext{
${ }^{16}$ We use a linear probability model for simplicity, particularly in the instrumental variables context. Our basic results were the same when a probit model was used.

${ }^{17}$ Frank M. Bass, A New Product Growth Model for Consumer Durables, 15 Mgmt. Sci. 215 (1969).
} 
individual-level data, but the model has also been applied to city-, state-, and country-level data. ${ }^{18}$

The $x_{i}^{\circ}$ terms are household observables. In the basic specification, these are age, education, income, gender, race, marital status, the presence of children, whether the respondent uses a computer at work, and whether the respondent runs a business from home. There is no time subscript since we have these data for 1997 only. Among nonowners, those with the highest reservation prices might be expected to be those with the most income, education, and so on. They will therefore be more likely to adopt if the market price falls.

The $x_{i t}^{\mathrm{u}}$ terms represent household unobservables that are correlated with the CITY $\%_{t-1}$ but uncorrelated with $x_{i}^{\circ}$. Although families probably do not reside in a particular city on the basis of their propensity to own computers, they may sort on the basis of characteristics that are correlated with that propensity. To contribute to $x_{i t}^{\mathrm{u}}$, however, the sorting must be over and above sorting on observables such as income, age, education, or use of a computer at work. We have in mind something like a level of technological sophistication that is correlated across households within cities but is not captured by the observables. Measurement error in $x_{i}^{\circ}$ (for example, errors in reported income or the difference between permanent and current income) could also contribute to $x_{i t}^{\mathrm{u}}$.

The $c_{i t}^{\mathrm{u}}$ terms are city-level unobservables such as the quality and price of Internet access, the price of computers, the density of computer stores, and advertising for computers. These city attributes may be endogenous responses to local computer purchases, a form of network externalities, but on the production side instead of on the consumption side. Finally, the $u_{i t}$ terms are idiosyncratic household unobservables, which could be correlated with household observables $x_{i}^{\circ}$.

The unobservable terms in (1) clarify the potential sources of bias in a regression of $y_{i t}$ on CITY\% ${ }_{t-1}$ and $x_{i}^{\circ}$. If CITY\% is positively correlated with $x_{i t}^{\mathrm{u}}+c_{i t}^{\mathrm{u}}$ conditional on $x_{i}^{\mathrm{o}}$, then the estimated local effect $(\hat{\lambda})$ will be biased upward. If people in Silicon Valley love technology, for example, they may be more likely to own computers and to buy them if they do not yet own them. This will spuriously make the spillover seem large. On the other hand, the estimates may be biased downward because of survivor bias. ${ }^{19}$ If the only people living in Silicon Valley who do not own computers in 1997 actually hate technology and will never buy a

\footnotetext{
${ }^{18}$ See the survey by Vijay Mahajan, Eitan Muller, \& Frank M. Bass, New Product Diffusion Models, in 5 Handbooks in Operations Research and Management Science 349 (J. Eliashberg \& G. L. Lilien eds. 1993), for empirical applications of the Bass model. Karshenas \& Stoneman, supra note 9 , also implements a hazard rate formulation on microlevel data, in this case, for individual firms that adopt numerically controlled machines.

${ }^{19}$ James J. Heckman \& Burton Singer, Social Science Duration Analysis, in Longitudinal Analysis of Labor Market Data 39 (James J. Heckman \& Burton Singer eds. 1985).
} 
computer, this will create a downward bias in our estimated $\hat{\lambda}$. In either case, the use of instrumental variables is necessary.

\section{Ordinary Least Squares Results}

We start by presenting the cross-sectional regression of household ownership on city ownership. The dependent variable is a binary variable that equals one if the individual owns a computer and zero otherwise; the independent variable of interest is the mean ownership rates of other people in the metropolitan area. The first column of Table 1 shows that a household is more likely to own a computer if other households in the same metropolitan area do (coefficient $=.294$, standard error $=.034, t$-statistic $=8.7$ ), even controlling for household characteristics such as education, income, age, and whether a computer is used at work. This coefficient is likely to be biased upward because of unobservable city features and correlated household unobservables. In contrast to this regression of ownership on contemporaneous ownership of others in the city, we now turn to regressions of first-time purchase on lagged ownership of others in the city.

We are more interested in the impact of lagged ownership on the probability of adoption (among those who have not adopted through the previous year) for two reasons. First, it may mitigate the bias from correlated household unobservables. By looking only at nonowners and asking if they are more likely to adopt if surrounded by more owners, we are isolating people who are demonstrably different from computer owners. Second and more important, the economic logic of learning and network externalities suggests that the stock should affect the flow. In the case of learning, a larger stock means that there are more owners from whom to learn how to use and buy a computer, which promotes adoption. In the case of network externalities, a larger stock means a larger network in which to participate. ${ }^{20}$

In column 2 of Table 2, we look at individuals who do not own a computer in 1996 and ask whether they were more likely to buy one in 1997 if there were many owners in their city in 1996. This is the specification of equation (1) above. The estimated coefficient on local ownership rates, $\lambda$, is positive and highly significant, which suggests that local spillovers may be important ${ }^{21}$

\footnotetext{
${ }^{20}$ In theory, what should matter is the expected size of the network over the entire lifetime of the computer. This could also apply to learning if adopters learn from other owners even after they have adopted. This is difficult to deal with appropriately since the path of computer ownership will be strongly affected by the hard-to-predict future rate of decline of computer prices.

${ }^{21}$ We obtained very similar results using the share of people in a city who either own a computer at home or use a computer at work for CITY\% (rather than just the share who own a computer at home). We also obtained similar results when we regressed 1996 adoption on 1995 ownership, 1995 adoption on 1994 ownership, and the self-reported probability of buying in 1998 on 1997 ownership.
} 
TABLE 2

Ordinary Least SQuares Results

\begin{tabular}{|c|c|c|c|c|c|}
\hline & $\begin{array}{c}\text { Ownership } \\
1997 \\
(1)\end{array}$ & $\begin{array}{c}\text { Adoption } \\
1997 \\
\text { (2) }\end{array}$ & $\begin{array}{l}\text { High versus } \\
\text { Low CITY\% } \\
\text { (3) }\end{array}$ & $\begin{array}{c}\text { More } \\
\text { Controls } \\
(4)\end{array}$ & $\begin{array}{l}\text { CITY\% for } \\
\text { Electronics } \\
\text { (5) }\end{array}$ \\
\hline \multicolumn{6}{|l|}{ CITY\%: } \\
\hline Year $t$ & $\begin{array}{c}.294 \\
(.034) \\
{[8.7]}\end{array}$ & & & & \\
\hline Year $t-1$ & & $\begin{array}{c}.104 \\
(.018)\end{array}$ & $\begin{array}{c}.122 \\
(.041)\end{array}$ & $\begin{array}{c}.111 \\
(.022)\end{array}$ & $\begin{array}{l}.119 \\
(.035)\end{array}$ \\
\hline Top quartile of CITY\% & & & $\begin{array}{l}.001 \\
(.010) \\
{[.1]}\end{array}$ & & \\
\hline Bottom quartile of CITY\% & & & $\begin{array}{c}.013 \\
(.013) \\
{[1.0]}\end{array}$ & & \\
\hline$N$ & 101,871 & 61,399 & 61,399 & 35,144 & 35,144 \\
\hline$R^{2}$ & .270 & .060 & .060 & .073 & .074 \\
\hline
\end{tabular}

NotE. - Standard errors are in parentheses; $t$-statistics are in brackets. The 10 demographic variables listed in Table 1 were included as controls in all regressions (and each variable was always highly significant). Each regression is a linear probability model. Column 1 regresses individual-level ownership in 1997 on the fraction of the city owning in 1997. Columns 2-5 regress the decision to buy a computer in 1997 (conditional on not owning a computer through 1996) on the share of the city owning a computer in 1996. More controls include three interactions of the demographic variables (income $\times$ education, education $\times$ age, and income $\times$ age), seven dummies for ownership of other consumer electronics (satellite dish, bigscreen TV, cordless phone, compact disc (CD) player, component stereo system, VCR, and answering machine), three "attitude toward technology" variables (self-ratings from 1 to 10 of how well the statements "I like technology," "technology is important to me," and "I like to spend time learning about new technology products" describe the respondent's personality), five dummies for categories for hours of TV watching, and five dummies for wealth categories. The CITY\% variable for electronics denotes the fraction of households in the city who own each of the seven consumer electronic goods (satellite dish, big-screen TV, cordless phone, CD player, component stereo system, VCR, and answering machine).

$(t$-statistic $=5.7){ }^{22}$ It is also economically important. The point estimate of .10 implies that, controlling for household observables, an increase of 10 percentage points in the city level of computer ownership will increase by 1 percent a nonowner's probability of making a purchase in 1997. This is substantial relative to the 1997 mean adoption rate for nonowners of 8 percent. $^{23,24}$ To illustrate the quantitative importance of the spillover implied by

${ }^{22}$ All of the standard errors in the paper are corrected for the fact that CITY\% does not vary by household.

${ }^{23}$ Coefficients on the demographic variables, not listed in Table 2, have predictable signs. Households with more income and education are more likely to buy their first computer. Using a computer at work, running a business from home, and having children in the household are also associated with a higher probability of first purchase. For example, having a child between the ages of 6 and 17 in the household means a 4.2 percentage point higher probability of buying. The largest marginal effect (as well as the largest $t$-statistic) is on using a computer at work. This raises the probability of purchase by 7 percentage points, almost doubling it at the mean of the covariates.

${ }^{24}$ The levels coefficient in column 1 of Table 2 may be higher than the adoption coefficient 
the point estimate for 1997, we sum equation (1) across households within a city to get

$$
\frac{f_{c t}}{1-F_{c, t-1}}=\lambda F_{c, t-1}+\beta x_{c}^{\mathrm{o}}+c_{t}^{\mathrm{u}}+x_{c t}^{\mathrm{u}},
$$

where $f_{c t}$ is the fraction of households in city $c$ that buy their first computer in year $t$ and $F_{c, t-1}\left(=\right.$ CITY $\left._{t-1}\right)$ is the fraction of households in city $c$ that own a computer in year $t-1$; that is, $f$ and $F$ are the density and cumulative density, respectively, of computer adoption (first-time computer purchase). When $\lambda>0$, the hazard is rising in the fraction of the population that own in the previous period. For nonowners, the 1997 hazard rate in our sample was approximately 8 percent, so the population-weighted left-hand side of the equation averaged 8 percent across our cities. Given our baseline estimate of $\lambda=.10$ and an average $F_{c, t-1}$ across cities of 40 percent in $1996, \lambda \times$ $F_{c, t-1}$ contributed 4 percentage points to the average 8 percent hazard rate. The remaining terms $\left(\beta x_{c}^{\mathrm{o}}+c_{t}^{\mathrm{u}}+x_{c t}^{\mathrm{u}}\right)$ contributed the other 4 percentage points. Thus, in 1997 one-half of the adoption rate may have come from local spillovers. In short, if our coefficient reflects spillovers, then spillovers substantially affect the speed of diffusion.

As this numerical exercise illustrates, computer adoption can spread even if there are no spillovers, say, because of decreasing computer prices interacting with the determinants of household reservation prices $\left(\beta x_{i}^{\mathrm{o}}+c_{i t}^{\mathrm{u}}+\right.$ $\left.x_{i t}^{\mathrm{u}}\right)$. Some of this will be picked up in our regressions by household observables $\left(\beta x_{i}^{\circ}\right)$ that predict which households have higher reservation prices and, hence, buy in response to the price decline. As noted earlier, a positive coefficient on lagged CITY\% could merely reflect a convex portion of fixed cumulative distribution of reservation prices (conditional on observables), with different cities representing different segments of the convex portion.

The spillover interpretation has the strong prediction that the adoption rate should be increasing in CITY\% over the entire range of CITY\%. This is not shared by most distributions that might characterize reservation prices (conditional on observables). A uniform distribution would imply a monotonically declining hazard rate. Any single-peaked, symmetric distribution, such as a normal distribution, would imply a declining hazard rate over at least the top half of the distribution. A lognormal distribution (as seems to characterize income, for example) would imply a declining hazard over even more of the distribution, as would any other single-peaked, right-skewed distribution. Over these ranges, this effect would lead to a negative coefficient on CITY\%.

A glance at Figure 2 reveals no obvious tendency for the slope coefficient to vary with CITY\%. We test this formally by adding two interaction variables to the regression: the interaction of CITY\% $(t-1)$ with a dummy for the city

in column 2 because of the cumulative nature of the levels regression and because it is more susceptible to the bias from common unobservables across people. 
being in the top quartile of CITY\% $(t-1)$ and with a dummy for the city being in the bottom quartile of CITY\% $(t-1)$. Column 3 of Table 2 shows that neither interaction variable is statistically or economically significant, which means that they are not different from the baseline coefficient. We cannot reject the hypothesis that the slope is the same in the top and bottom quartiles of CITY\% ( $p$-value $=.53$ ). We also tried this regression for other cuts of the data, and in all cases we found a significant positive coefficient on CITY\% in every segment. ${ }^{25}$ In short, as predicted by the presence of spillovers, the adoption rate appears to be increasing in CITY\% across all ranges.

We next add variables that are plausibly correlated with an individual's level of sophistication. If the results are due to unobserved technological sophistication instead of spillovers, then adding these variables should reduce the coefficient on CITY\%. In column 4 of Table 2, we add 23 additional controls to our original set of 10 demographic controls: three interactions of the demographic variables (income $\times$ education, education $\times$ age, and income $\times$ age), seven dummies for ownership of other consumer electronics (satellite dish, big-screen television, cordless phone, compact disc (CD) player, component stereo system, VCR, and answering machine), three "attitude toward technology" variables (self-ratings from 1 to 10 of how well the statements "I like technology," "technology is important to me," and "I like to spend time learning about new technology products" describe the respondent's personality), five dummies for categories for hours of television watching, and five dummies for wealth categories.

Of the 23 additional controls, 17 are statistically significant: nine at the 1 percent level, five more at the 5 percent level, and three more at the 10 percent level. The three individually most significant are ownership of a CD player $(t$-statistic $=9.5)$, "technology is important to me" $(t$-statistic $=$ $6.5)$, and ownership of a cordless phone ( $t$-statistic $=-6.3)$. The inclusion of these extra, significant controls causes the coefficient on CITY\% to fall slightly from .119 to .111 (standard errors $=.022$ ) ${ }^{26}$ Since we think these additional controls are likely to be correlated with a household's unobserved sophistication (and permanent income), the fact that the CITY\% coefficient survives almost wholly intact makes us more confident that the estimated

\footnotetext{
${ }^{25}$ We found the same effect when interactions were used with the top and bottom deciles instead of quartiles. Neither coefficient was significantly different from the baseline coefficient, and we could not reject that the top and bottom deciles were the same ( $p$-value $=.42)$. We also tried an interaction with the sample split only in half. We found that the top half of the CITY\% sample had a smaller (but still positive) point estimate, and the difference was only borderline significant $(p$-value $=.11)$.

${ }^{26}$ Because many people have missing values for at least one of the additional variables, the sample size in Table 2 is considerably smaller in column 4 than in column 2 . The baseline regression coefficient with this smaller sample is .119 , compared with .104 with the larger sample.
} 
CITY\% coefficient does not merely reflect the correlation between CITY\% and $x_{i t}^{\mathrm{u}}$.

We next add variables motivated by the debate over the impact of computers on wages. John DiNardo and Jorn-Steffen Pischke show that while using a computer seems to raise wages, so do using a pencil and sitting down while working. ${ }^{27}$ Further, controlling for pencil use and working while sitting often lowers the estimated wage effect of computers substantially. They argue that this casts doubt on a causal interpretation of the computer coefficient.

To apply this to our context, column 5 of Table 2 adds to the regression of column 4 the fraction of households in the city that own each of seven consumer electronic goods (satellite dish, big-screen television, cordless phone, CD player, component stereo system, VCR, and answering machine). We do not think there are plausible learning or network benefits for computer adoption arising from widespread use of stereos, VCRs, and so on. Thus, if these variables matter and lower the coefficient on the fraction of people owning computers, it would cast doubt on a spillover interpretation. We find in column 5 that the results change little. The local effect of computer ownership is still positive and significant $(t$-statistic $=3.4)$, and the magnitude is the same as in the baseline regression. Although we do not list the other coefficients for space reasons, none of the seven ownership fractions is significantly positive, and the same is true when we add them individually rather than collectively. ${ }^{28}$ To summarize, adding variables likely to be correlated with unobservable sophistication (and permanent income) does not change the estimated importance of spillovers.

\section{InSTRUMENTAL VARIABLES}

To address potential simultaneity problems with estimating local spillovers, we now carry out instrumental variables estimation. We use as instruments the city means of the 10 household variables (education, income, age, and so on; see Table 1). Positive local externalities mean that, conditional on its characteristics, a household should be more likely to buy its first computer if it is surrounded by households with observables favorable to computer ownership. For example, a childless household surrounded by households with children should be more likely to adopt than a childless household

\footnotetext{
${ }^{27}$ John E. DiNardo \& Jorn-Steffen Pischke, The Returns to Computer Use Revisited: Have Pencils Changed the Wage Structure Too? 112 Q. J. Econ. 253 (1997).

${ }^{28} \mathrm{We}$ also reestimated the column 5 specification with dummies for 15 income categories, five education categories, and three age categories instead of single variables for income, education, and age. The coefficient actually rose a negligible amount, from .119 to .121.
} 
surrounded by childless households. Thus, the city means should be relevant instruments, and they are (first-stage $R^{2}=.88$ ). ${ }^{29}$

The city mean observables $\left(x_{c}^{\circ}\right)$ will not be valid instruments if they are correlated with household unobservables $\left(x_{i}^{\mathrm{u}}\right)$. One might worry that they are positively correlated because, say, cities with many children are filled with the more technologically savvy. But household observables are included in the regression. This means that any correlation between unobservables and observables should not bias the coefficient on CITY\%, only the $\beta$ coefficients on the observables themselves. For example, the coefficient on children in the household should absorb any correlation between the household's sophistication and the presence of children. For this reason, city mean observables should not be correlated with $x_{i}^{\mathrm{u}}$ simply because cities with many children tend to be filled with technological sophisticates. It would have to be that, when we control for whether a household includes children, a household tends to be more savvy the higher the fraction of households in the city with children.

As column 2 of Table 3 shows, using these 10 city mean variables as instruments gives a similar answer to ordinary least squares: .115 versus the .104 OLS estimate in column 1. The CITY\% coefficient is still estimated quite precisely ( $t$-statistic $=6.1)$. It is important to note that we cannot reject the nine overidentifying restrictions at the 5 percent level $(p$-value $=.16){ }^{30}$ The weakest a priori case for city mean validity is likely to be for the city mean income, education, and work variables (use a computer at work or run a business from home). Column 3 drops the work variables from the instrument set; column 4 drops the income and education variables from the instrument set; and column 5 drops the work, income, and education variables from the instrument set. In every case, the instrumental variables estimate lies between .11 and .13 , with a $t$-statistic of at least 5.5 (compared with a coefficient of .12 and a $t$-statistic of 6.1 with all 10 city means as instruments). Finally, we think the strongest a priori case for validity might be made for the city mean percentage of households with children aged $6-17$. When we use only this variable as an instrument in column 6 of Table 3, we still find a significant CITY\% coefficient, albeit with larger standard errors. Adoption is more likely if a household is surrounded by households with children, when we control for whether the household has children or not (and household

\footnotetext{
${ }^{29}$ Anne C. Case \& Lawrence F. Katz, The Company You Keep: The Effects of Family and Neighborhood on Disadvantaged Youths (Working Paper No. 3705, Nat'l Bur. Econ. Res. 1991), develops this insight and proposes a likelihood ratio test of, in our example, whether the city means for the observables matter for individual decisions. When we performed this test using our data, we easily rejected the hypothesis that there are no local effects.

${ }^{30}$ In testing the overidentifying restrictions, we take account of the fact that the data are grouped by city using the technique in Caroline Hoxby \& M. Daniele Paserman, Overidentification Tests with Grouped Data (Tech. Working Paper No. 223, Nat'l Bur. Econ. Res. 1998).
} 
TABLE 3

INSTRUMENTAL VARIABLES

\begin{tabular}{|c|c|c|c|c|c|c|}
\hline & \multirow[b]{2}{*}{$\begin{array}{c}\text { OLS } \\
\text { BASELINE } \\
\text { (1) }\end{array}$} & \multicolumn{5}{|c|}{ IV City Means } \\
\hline & & $\begin{array}{c}\text { For } 10 \\
\text { Demographic } \\
\text { Variables } \\
(2)\end{array}$ & $\begin{array}{l}\text { Excluding } \\
\text { Work } \\
\text { Variables } \\
\text { (3) }\end{array}$ & $\begin{array}{l}\text { Excluding } \\
\text { Income and } \\
\text { Education } \\
\text { (4) }\end{array}$ & $\begin{array}{c}\text { Excluding } \\
\text { Work, Income, and } \\
\text { Education } \\
\text { (5) }\end{array}$ & $\begin{array}{c}\text { For } \\
\text { Children } \\
\text { Only } \\
(6)\end{array}$ \\
\hline \multirow{2}{*}{$\begin{array}{l}\text { CITY\% } \\
\quad(\text { year } t-1)\end{array}$} & & & & & & \\
\hline & $\begin{array}{c}.104 \\
(.018) \\
{[5.7]}\end{array}$ & $\begin{array}{c}.115 \\
(.019) \\
{[6.1]}\end{array}$ & $\begin{array}{c}.117 \\
(.019) \\
{[6.1]}\end{array}$ & $\begin{array}{c}.112 \\
(.020) \\
5.8]\end{array}$ & $\begin{array}{c}.127 \\
(.023) \\
{[5.5]}\end{array}$ & $\begin{array}{c}.168 \\
(.053) \\
{[3.2]}\end{array}$ \\
\hline First-stage $R^{2}$ & & .88 & .85 & .84 & .56 & .16 \\
\hline
\end{tabular}

NoтE. -Standard errors are in parentheses; $t$-statistics are in brackets; $N=61,399 ; R^{2}=.060$. Each regression is a linear probability model. The 10 demographic variables listed in Table 1 were included as controls in all regressions. Column 2 uses as instruments the city means of the 10 demographic variables (income, education, age, and dummies for children aged 6-17, female, single, Asian, non-Asian minority, use a computer at work, and run a business from home). Column 3 uses the first eight of these as instruments (that is, excludes the variables use a computer at work and run a business from home). Column 4 uses the last eight of these as instruments (that is, excludes income and education). Column 5 uses the middle six of these (that is, excludes the work variables and the income and education variables). Column 6 uses only the variable children aged $6-17$ as an instrument.

income, education, and so on): the coefficient is .168, with a standard error of .053 and $t$-statistic of 3.2 .

To summarize, the instrumental variables results do not support the interpretation of the CITY\% coefficient as resulting from simultaneity bias.

\section{Identifying the Type of Network}

If the CITY\% coefficient arises from spillovers, then we would like to know more about the channel and nature of the spillover. In this section, we try to determine whether certain users are more influential than others, whether local schools are an important channel, whether local computer retailers play a special role, and whether any externalities might operate through the use of software, e-mail, or the Internet.

\section{A. Spillovers by Type of Owner}

Using the information in the survey on how many computers a household has ever owned, we divide city ownership into two groups: people who have owned two or more computers in their lifetime (19 percent of all households at the end of 1996) and people who have owned only one computer in their lifetime (also 19 percent of all households at the end of 1996). We would expect nonowners to have more traits in common with people owning their first computers than with experienced owners, so if the correlated unobservables explanation is correct, there should be particularly high rates of adoption among nonusers in places where there are many first-time owners, and the 
TABLE 4

IDENTIFYING THE TyPE OF Network

\begin{tabular}{|c|c|c|c|c|c|}
\hline Variables & $\begin{array}{l}\text { Number } \\
\text { Bought } \\
\text { (1) }\end{array}$ & $\begin{array}{l}\text { Intensity } \\
\text { of Use } \\
\text { (2) }\end{array}$ & $\begin{array}{c}\text { No Children } \\
\text { (3) }\end{array}$ & $\begin{array}{c}\text { City-States } \\
\text { (4) }\end{array}$ & $\begin{array}{c}\text { City } \\
\text { Dummies } \\
(5)\end{array}$ \\
\hline CITY\% & & & $\begin{array}{c}.094 \\
(.185) \\
{[5.1]}\end{array}$ & $\begin{array}{l}.011 \\
(.043) \\
{[.3]}\end{array}$ & \\
\hline CITY-STATE\% & & & & $\begin{array}{c}.094 \\
(.039) \\
{[2.4]}\end{array}$ & $\begin{array}{c}.088 \\
(.033) \\
{[2.6]}\end{array}$ \\
\hline \multicolumn{6}{|l|}{ CITY\%: } \\
\hline Two or more computers & $\begin{array}{c}.123 \\
(.024) \\
{[5.3]}\end{array}$ & & & & \\
\hline One computer & $\begin{array}{c}.061 \\
(.056) \\
{[1.1]}\end{array}$ & & & & \\
\hline Heavy use & & $\begin{array}{c}.137 \\
(.025) \\
{[5.4]}\end{array}$ & & & \\
\hline Light use & & $\begin{array}{c}-.007 \\
(.075) \\
{[.1]}\end{array}$ & & & \\
\hline$N$ & 61,399 & 61,399 & 47,929 & 61,399 & 61,399 \\
\hline$R^{2}$ & .060 & .060 & .051 & .060 & .064 \\
\hline
\end{tabular}

NoTE. - Standard errors are in parentheses; $t$-statistics are in brackets. The 10 demographic variables listed in Table 1 were included as controls in all regressions (except column 3, which excluded the children aged 6-17 variable). Each regression is a linear probability model. Column 3 restricts the sample to individuals with no children.

coefficient on that group should be larger. On the other hand, if the spillover explanation is correct, since multiple-computer owners are likely to be better informed, have more software to share, and so on, the coefficient on experienced users should be larger. The results, presented in column 1 of Table 4, show that multiple lifetime purchasers are substantially more influential. The coefficient on the fraction of city households that are multiple lifetime purchasers is .123 (standard error $=.024, t$-statistic $=5.3$ ), while the coefficient for single-computer purchasers is .061 (standard error $=.056, t$ statistic $=1.1$.

Similarly, in column 2 of Table 4, we classify computer owners into two usage groups. We define households that report using a computer more than 20 days per month as "heavy users" and those that use it fewer than 20 days per month as "light users." From this, we decompose CITY\% into two shares: those who use a computer more than 20 days per month and those who use a computer fewer than 20 days per month (these average 26 percent and 12 percent of households, respectively). Again, we expect the unobserved traits of the light users to be most like those of the nonowners, whereas any spillovers should be more important from the heavy users. Again, the results 
show that the coefficient is much larger on the group that is less likely to share unobserved common traits (.137 for heavy users versus -.007 for light users). Indeed, the light users seem to confer no significant spillovers at all.

These results cast further doubt on an "unobserved common traits" interpretation and suggest that any spillovers arise disproportionately from experienced, intensive users.

\section{B. Local Schools}

One potential explanation for the city ownership coefficient is that it is being driven by computer use in local schools. School districts in which many families own computers may, for example, draft curricula that encourage nonowning families to buy a computer. In column 3 of Table 4, we include only households without school-aged children (hence the smaller number of observations and the absence of the children demographic control). The coefficient on city ownership (of all households, those with and without children aged 6-17) is again significant and has a similar magnitude (.094 versus .104 baseline). The school system cannot directly explain the local spillovers for these households. The school system may be an important conduit of learning and network benefits of computers, but this regression suggests that those benefits are not restricted to families with children in school.

\section{Local Prices}

Another possible explanation for our local effect is that cities with computer owners have large numbers of people who work in the computer industry, or they may have lower computer store prices, denser networks of computer stores, and cheaper access to the Internet. This may increase the probability of buying and thus explain our coefficient. ${ }^{31}$ This local effect could itself arise because of network externalities. Cities with many computerowning households may endogenously have a dense network of computer retailers and local phone numbers to access the Internet, thereby attracting new adopters.

To test this explanation, we examine the geographic areas in more detail. Thus far, we have been grouping households according to metropolitan area. For each person, we also have the state they live in, as many of the met-

\footnotetext{
${ }^{31}$ Fixed city price differences are actually not sufficient to generate a positive correlation between CITY\% and the adoption rate of nonowners. For nonowners, the local market price has until now exceeded their reservation price. If the distribution of reservation prices across households is uniform between 0 and $P$ (so that low-price cities have higher ownership), then low-price cities would need to have more rapidly decreasing computer prices in percentage terms; that is, one would need price divergence, not just price-level differences. If the distribution of reservation prices is nonuniform, however, then level differences in city prices could produce positive or negative local effects.
} 
ropolitan areas cross state boundaries. The New York City area, for example, includes people in New Jersey and Connecticut. We therefore create a narrower local area, the "city-state." This splits a city like New York into three different city-states: New York-New York, New York-New Jersey, and New York-Connecticut. We then create the fraction of ownership within each of these city-states.

In column 4 of Table 4, we repeat our standard regression, but with the ownership shares by both city-state and city. The evidence is quite clear that the effect is at the more local, city-state level (the coefficient on CITYSTATE\% is .094 versus only .011 on CITY\%). In column 5, we add city dummies that should absorb any metropolitan-area-level differences in industry composition, Internet access, computer store availability, computer advertising, and so on. The coefficient on the local spillover remains large, positive, and significant (the coefficient is .088, with a standard error of .033). Thus, the local effect cannot be explained by differences in any citywide features. ${ }^{32}$ To explain the results, prices and other features would have to differ systematically within metropolitan areas. Because of these results, in the regressions that follow, we will use CITY-STATE\% instead of CITY\% (although very similar results obtain with CITY\%).

Of course, adjacent city-states may indeed have different levels of computer prices, Internet access, and so on. Fortunately, we are able to examine the issue from another angle by using the information given by end-of-1997 nonowners on how likely they are to buy a computer in the next year (1998). These same respondents were also asked how many of their family and friends own personal computers (potential answers being "all," "most," "some," "very few," and "none").

Column 1 of Table 5 shows a regression of the reported likelihood of buying on dummies for the share of friends and family who use computers, the fraction of the city-state that owns computers, and our standard list of household observables. The results show that the larger the fraction of family and friends who own a computer, the higher the reported likelihood of a first purchase in the next year. Going from "none" to "all" of friends and family owning computers raises the reported likelihood by .21 , a considerable amount relative to the mean likelihood of .25. The friends and family dummies are highly significant, with $t$-statistics ranging from 9 to 40 . Importantly, their inclusion renders the estimated spillover at the city-state level small and insignificant: .032, with a standard error of .019. (The regression with the same dependent variable but no friends and family dummies yielded a

\footnotetext{
${ }^{32}$ A variant of the local price hypothesis is that the presence of computer owners affects adoption through the market for used computers. Cities with many owners may have many inexpensive or free old computers. Our data contain information for some respondents on the type of store in which they purchased their computer. Using this information, we found the same spillovers from local ownership as when we looked only at the decision to buy a new computer.
} 
TABLE 5

THe Localized NeTwork

\begin{tabular}{|c|c|c|}
\hline & $\begin{array}{l}\text { Friends and Family } \\
\text { (1) }\end{array}$ & $\begin{array}{c}\text { Friends and } \\
\text { Family with } \\
\text { City-State Dummies } \\
\text { (2) }\end{array}$ \\
\hline CITY-STATE\% & $\begin{array}{c}.032 \\
(.019) \\
{[1.7]}\end{array}$ & \\
\hline \multicolumn{3}{|c|}{ Friends and family with computers: } \\
\hline All & $\begin{array}{c}.210 \\
(.011) \\
{[20.0]}\end{array}$ & $\begin{array}{c}.209 \\
(.011) \\
{[19.7]}\end{array}$ \\
\hline Most & $\begin{array}{c}.199 \\
(.005) \\
{[40.8]}\end{array}$ & $\begin{array}{c}.200 \\
(.005) \\
{[40.8]}\end{array}$ \\
\hline Some & $\begin{array}{c}.115 \\
(.005) \\
{[24.4]}\end{array}$ & $\begin{array}{c}.116 \\
(.005) \\
{[24.2]}\end{array}$ \\
\hline Very few & $\begin{array}{c}.043 \\
(.005) \\
{[9.2]}\end{array}$ & $\begin{array}{c}.045 \\
(.005) \\
{[9.6]}\end{array}$ \\
\hline$R^{2}$ & .261 & .268 \\
\hline
\end{tabular}

Note. - Standard errors are in parentheses; $t$-statistics are in brackets; $N=52,868$. The 10 demographic variables listed in Table 1 were included as controls in all regressions. The dependent variable is the selfreported likelihood of buying a computer in 1998. Column 2 includes dummies for the individual's citystate of residence.

coefficient of .105, with a standard error of .026.) Column 2 of Table 5 shows that adding city-state dummies does not materially change the estimated effects of ownership by friends and family.

The fact that friends and family dummies eclipse CITY-STATE\% represents, in our view, strong evidence against the view that unobserved citystate features (prices, Internet access, computer ads, and computer store density) explain the significance of CITY-STATE\% in other regressions. For variables such as prices to explain the importance of CITY\%, the prices would need to be more specific to the household and its friends and family than to the city-state in which the household resides.

These "friends and family" results could, of course, also be explained by common unobserved traits among friends and family. Correlation with unobserved traits is surely responsible for some of the explanatory power of the friends and family dummies. ${ }^{33}$ But the correlation between the friends and

\footnotetext{
${ }^{33}$ Comparison of the $R^{2}$ of .26 with friends and family variables (Table 5) with the $R^{2}$ values of around .06 in Table 4 overstates their explanatory power. Table 5 uses a more continuous dependent variable (likelihood of buying for the first time in 1998 of $0, .1, \ldots, .9$ ) than the other regressions (dependent variable equal to 1 for adopters, 0 for nonadopters) and hence naturally has a higher $R^{2}$. The proper comparison is to a regression with the same dependent variable but no friends and family dummies, which has an $R^{2}$ of .23 rather than .26 . Thus, although the friends and family dummies noticeably improve the fit, their tremendous significance also comes at the expense of the significance of the other demographic variables.
} 
TABLE 6

NeTWORKS BY TYPE OF UsE

\begin{tabular}{|c|c|c|c|c|c|c|c|c|}
\hline Variables & $\begin{array}{c}\text { Word Processing } \\
\text { (1) }\end{array}$ & $\begin{array}{c}\text { Spreadsheet } \\
\text { (2) }\end{array}$ & $\begin{array}{l}\text { Games } \\
\text { (3) }\end{array}$ & $\begin{array}{c}\text { Graphics } \\
\text { (4) }\end{array}$ & $\begin{array}{l}\text { Family Budget } \\
\text { (5) }\end{array}$ & $\begin{array}{c}\text { Work at Home } \\
\text { (6) }\end{array}$ & $\begin{array}{l}\text { Internet } \\
(7)\end{array}$ & $\begin{array}{c}\text { E-Mail } \\
(8)\end{array}$ \\
\hline \multicolumn{9}{|l|}{ CITY-STATE\%: } \\
\hline \multirow[t]{2}{*}{ Frequently use feature } & .106 & .093 & .110 & $\begin{array}{l}.099 \\
(055)\end{array}$ & .120 & .064 & .134 & .144 \\
\hline & {$[6.0]$} & {$[2.3]$} & $\begin{array}{l}(.031) \\
{[3.5]}\end{array}$ & $\begin{array}{l}(.055) \\
{[1.8]}\end{array}$ & $\begin{array}{l}(.044) \\
{[2.7]}\end{array}$ & $\begin{array}{l}(.034) \\
{[1.9]}\end{array}$ & $\begin{array}{l}(.020) \\
{[6.6]}\end{array}$ & $\begin{array}{l}(.022) \\
{[6.6]}\end{array}$ \\
\hline \multirow[t]{3}{*}{ Do not frequently use feature } & .096 & .115 & .097 & .107 & .0964 & .153 & .046 & .030 \\
\hline & $(.067)$ & $(.036)$ & (.037) & $(.028)$ & $(.0289)$ & $(.038)$ & (.039) & $(.040)$ \\
\hline & [1.4] & {$[3.2]$} & {$[2.6]$} & [3.9] & [3.3] & [4.0] & {$[1.2]$} & {$[.8]$} \\
\hline$p$-Value on equality & .89 & .74 & .81 & .92 & .72 & .17 & .07 & .03 \\
\hline$R^{2}$ & .061 & .064 & .061 & .061 & .061 & .061 & .061 & .061 \\
\hline
\end{tabular}

Note. -Standard errors are in parentheses; $t$-statistics are in brackets; $N=61,399$. The 10 demographic variables listed in Table 1 were included as controls in all regressions. Each regression is a linear probability model. 
family dummies and CITY\% need not result from common unobserved traits. We presented several lines of evidence that cast doubt on the common-traits interpretation of the CITY\% coefficient. We think the evidence, taken together, suggests that friends and family variables render the CITY\% coefficient insignificant because friends and family with computers are the channel by which CITY\% enters significantly. It seems plausible that the spillovers occur among friends and family members-precisely the people a household interacts with most. Friends and family may be the people with whom one exchanges most e-mail from home, most software used at home, and so on. ${ }^{34}$

\section{Software, the Internet, and E-Mail Networks}

In Table 6, we present a series of regressions, each of which breaks CITYSTATE\% into computer users who do and do not report using their computer frequently for specific activities. If there are networks associated with sharing software files, for example, we might expect that spreadsheet or word processor users would have more influence on new adopters than those who do not use those types of software. The first five columns of Table 6 reveal that spillovers from computer owners are equally strong from users and nonusers of word processors, spreadsheets, games, graphics, and family budgeting-precisely the types of software where file sharing might be prevalent.

Column 6 shows that spillovers do not appear to be from those who use their home computers for work. The spillovers appear larger from those who do not use their computers to do work at home than from those who do, although the difference is not significant at the 10 percent level.

More significant, columns 7 and 8 of Table 6 are consistent with the view that computers are components of local communication and information networks. In these columns we find that users who frequently use the Internet and e-mail appear more influential. The coefficient on Internet households is .134 versus only .046 on other households (the $p$-value that the coefficients are the same is .07). The coefficient on e-mail users is .144 versus .030 on those who do not use e-mail (the $p$-value on their equality is .03). These are suggestive of local communications networks but are also consistent with local learning if Internet and e-mail users are more knowledgeable than other

\footnotetext{
${ }^{34}$ We do not know how geographically close friends and family typically are, but the learning and network stories involve interaction, not proximity per se. We do not give these friends and family results a more central place in the paper because friends and family computer ownership is asked only of households that do not own a computer at the end of 1997. Thus, for example, we do not have this information for households that actually bought a computer in 1997. Moreover, we cannot observe the fraction of friends and family who use computers intensively and so on, whereas we can observe the fraction of households in the city that do so.
} 
computer owners or are more active in communicating with others. ${ }^{35}$

\section{CONCLUSION}

Using microlevel data on 110,000 U.S. households in 1997, we find that local spillovers are important for household computer adoption: households are more likely to buy their first computer when a high fraction of people around them already own computers (and especially when a high fraction of people around them are experienced, intensive users). Our point estimates imply that such spillovers could play a quantitatively important role in the spread of home computers, perhaps doubling the rate of adoption.

Applying a battery of tests, we find that this effect is robust and unlikely to be explained by common unobserved local traits or by alternative explanations such as local computer prices, local industry composition, local schools, or peer pressure. The networks do not appear to be tied to any particular type of software or to the use of an at-home computer for work. Instead, networks seem related to use of the Internet and e-mail, consistent with computers as the hub of information and communications networks.

If these spillovers are, indeed, externalities, they may provide backing for efforts to close the digital divide between those with and without Internet and computer access. These efforts might take the form of existing subsidies to library and public school Internet access. Our results suggest that the most effective way to do this would be by promoting experienced, intensive users, especially those who interact with subgroups who have low rates of computer adoption. Even if the spillovers are not, in fact, externalities, their existence means that the cumulative impact of subsidies will be significantly greater than their immediate impact.

\section{BIBLIOGRAPHY}

Autor, David H.; Katz, Lawrence F.; and Krueger, Alan B. "Computing Inequality: Have Computers Changed the Labor Market?" Quarterly Journal of Economics 113 (1998): 1169-1213.

Baily, Martin Neil, and Lawrence, Robert Z. "Do We Have a New Economy?" American Economic Review 91 (2001): 308-12.

Bass, Frank M. "A New Product Growth Model for Consumer Durables." Management Science 15 (1969): 215-27.

\footnotetext{
${ }^{35}$ We do not know what share of e-mail traffic goes to local users or what fraction of Web browsing involves local-content Web sites. When people with on-line access are asked what they usually do on-line, one top answer does not appear to be particularly local (42 percent usually visit reference sites), but five of the next six may include significant local content (45 percent visit product or company Web sites, 37 percent check the weather, 29 percent read a daily newspaper, 25 percent visit a sports site, and 24 percent participate in on-line chats). A larger local pool of on-line computer owners means, perhaps, an endogenously greater supply of Web sites with local information.
} 
Berndt, Ernst R.; Pindyck, Robert S.; and Azoulay, Pierre. "Consumption Externalities and Diffusion in Pharmaceutical Markets: Antiulcer Drugs." Working Paper No. 7772. Cambridge, Mass.: National Bureau of Economic Research, 2000.

Bernhoff, Josh; Morrisette, Shelley; and Clemmer, Kenneth. "Technographics Service Explained." Forrester Report 1, No. 0 (January 1998), p. 1.

Bresnahan, Timothy F., and Greenstein, Shane. "Technical Progress and Coinvention in Computing and in the Uses of Computers." Brookings Papers on Economic Activity: Microeconomics (1996), pp. 1-77.

Bresnahan, Timothy F.; Stern, Scott; and Trajtenberg, Manuel. "Market Segmentation and the Sources of Rents from Innovation: Personal Computers in the Late 1980s." Rand Journal of Economics 28, Suppl. (1997): 17-44.

Bresnahan, Timothy F., and Trajtenberg, Manuel. "General Purpose Technologies: 'Engines of Growth'?" Journal of Econometrics 65 (1995): 83-108.

Case, Anne C., and Katz, Lawrence F. "The Company You Keep: The Effects of Family and Neighborhood on Disadvantaged Youths." Working Paper No. 3705. Cambridge, Mass.: National Bureau of Economic Research, 1991.

Chari, V. V., and Hopenhayn, Hugo. "Vintage Human Capital, Growth, and the Diffusion of New Technology." Journal of Political Economy 99 (1991): 1142-55.

David, Paul A. "Clio and the Economics of QWERTY." American Economic Review 75 (1985): 332-37.

DiNardo, John E., and Pischke, Jorn-Steffen. "The Returns to Computer Use Revisited: Have Pencils Changed the Wage Structure Too?" Quarterly Journal of Economics 112 (1997): 253-90.

Dybvig, Philip H., and Spatt, Chester S. "Adoption Externalities as Public Goods." Journal of Public Economics 20 (1983): 231-47.

Economides, Nicholas. "Economics of Networks." International Journal of Industrial Organization 14 (1996): 673-700.

Farrell, Joseph, and Saloner, Garth. "Standardization, Compatibility and Innovation." Rand Journal of Economics 16 (1985): 70-83.

Foster, Andrew, and Rosenzweig, Mark. "Learning by Doing and Learning from Others: Human Capital and Technological Change in Agriculture." Journal of Political Economy 103 (1995): 1176-1209.

Gandal, Neil. "Hedonic Price Indexes for Spreadsheets and an Empirical Test for Network Externalities." Rand Journal of Economics 25 (1994): 160-70.

Gilbert, Richard J. and Katz, Michael L. "An Economist's Guide to U.S. v. Microsoft." Journal of Economic Perspectives 15 (Spring 2001): 25-44.

Goolsbee, Austan. "In a World without Borders: The Impact of Taxes on Internet Commerce." Quarterly Journal of Economics 115 (2000): 561-76.

Gowrisankaran, Gautam, and Stavins, Joanna. "Network Externalities and 
Technology Adoption: Lessons from Electronic Payments.” Unpublished manuscript. Minneapolis: University of Minnesota, 2001.

Greenwood, Jeremy, and Yorukoglu, Mehmet. "1974." Carnegie-Rochester Conference Series on Public Policy 46 (1997): 49-95.

Griliches, Zvi. "Hybrid Corn: An Exploration in the Economics of Technological Change." Econometrica 25 (1957): 501-22.

Grossman, Gene M., and Helpman, Elhanan. Innovation and Growth in the Global Economy. Cambridge, Mass.: MIT Press, 1991.

Hausman, Jerry. "Taxation by Telecommunications Regulation." In Volume 12 of Tax Policy and the Economy, edited by James M. Poterba. Cambridge, Mass.: MIT Press, 1998.

Heckman, James J., and Singer, Burton. "Social Science Duration Analysis." In Longitudinal Analysis of Labor Market Data, edited by James J. Heckman and Burton Singer, pp. 39-58. Cambridge: Cambridge University Press, 1985.

Heckman, James J., and Snyder, James M. "Linear Probability Models of the Demand for Attributes with an Empirical Application to Estimating the Preferences of Legislatures." Rand Journal of Economics 28 (1997): S142-S189.

Hoxby, Caroline, and Paserman, M. Daniele. "Overidentification Tests with Grouped Data." Technical Working Paper No. 223. Cambridge, Mass.: National Bureau of Economic Research, 1998.

Irwin, Douglas A., and Klenow, Peter J. "Learning by Doing Spillovers in the Semiconductor Industry." Journal of Political Economy 102 (1994): 1200-27.

Jaffe, Adam; Trajtenberg, Manuel; and Henderson, Rebecca. "Geographic Localization of Knowledge Spillovers as Evidenced by Patent Citations." Quarterly Journal of Economics 108 (1991): 577-98.

Karshenas, Massoud, and Stoneman, Paul L. "Rank, Stock, Order, and Epidemic Effects in the Diffusion of New Process Technologies: An Empirical Model." Rand Journal of Economics 24 (1993): 503-28.

Katz, Michael, and Shapiro, Carl. "Technology Adoption in the Presence of Network Externalities." Journal of Political Economy 94 (1986): 822-41.

Liebowitz, S. J., and Margolis, Stephen E. "Network Externality: An Uncommon Tragedy." Journal of Economic Perspectives 8 (Spring 1994): $133-50$.

MacCarthaigh, Sean. “Technology Town.” Irish Times, November 14, 1997.

Mahajan, Vijay; Muller, Eitan; and Bass, Frank M. "New Product Diffusion Models." In Volume 5 of Handbooks in Operations Research and Management Science, edited by J. Eliashberg and G. L. Lilien, pp. 349-408. Amsterdam: North-Holland, 1993.

Parente, Stephen L., and Prescott, Edward C. "Barriers to Technology Adoption and Development." Journal of Political Economy 102 (1994): 298-321. 
Rogers, Everett M. Diffusion of Innovations. 4th edition. New York: Free Press, 1995.

Saloner, Garth, and Shepard, Andrea. "Adoption of Technologies with Network Effects: An Empirical Examination of the Adoption of Automated Teller Machines." Rand Journal of Economics 26 (1995): 479-501.

U.S. Bureau of the Census. Current Population Reports. Series P60-200, Money Income in the United States: 1997. Washington, D.C.: U.S. Government Printing Office, 1998.

Yaukey, John. "Blacksburg, Va.: A Town That's Really Wired." Ithaca Journal, April 8, 1997. 